\title{
An Analysis of the Application of WeChat Public signal in University Library
}

\author{
Yang Xing \\ Jilin Agricultural University, Changchun 130118, China \\ 37566208@qq.com
}

Keywords: WeChat public signal; university library; intelligent service.

\begin{abstract}
In recent years, the application of WeChat public signal is very wide in many different areas. Colleges and universities also conform to the development of the times, in carrying out a lot of daily activities when the use of WeChat public single to bring some convenience for the work, especially the work of university libraries. This paper analyzes the application of micro - public letter in university library.
\end{abstract}

\section{Introduction}

WeChat as a new type of social software in the launch immediately after the majority of users loved. WeChat is powerful, you can easily and interaction with Net friends. the operation is also very simple, you can bind with other software. WeChat service platform for a wider range of applications, many companies set up public singles in the WeChat service platform, university libraries are no exception. Library managers should also actively follow the trend, the establishment of WeChat public platform in order to providing quality mobile services to teachers and students.

\section{2. the university library of WeChat public number mode of operation}

In recent years, the university library has registered the WeChat public number, to introduce the library's own situation, publish some of the library information, to the reader to promote and so on. University Library's WeChat public number of the main contents of the following.

\subsection{Library introduction and guide.}

Library managers in the WeChat public on the library, such as open time, into the library required documents, the type of library books and the number of borrowing process and so on. Library managers through the micro-public letter so that readers can have a clear understanding of the library, so that they understand the library's borrowing process, etc., so that readers can their own time to scientific and rational planning, to avoid wasting time.

\subsection{Release the relevant information.}

Library managers through the WeChat public single platform, will want to publish the information through the WeChat public single pushed to the reader, so that readers can pass the public number to understand the latest situation of the library.

\subsection{Promotion of Activities.}

In the library to hold some reading activities, the library manager with the public to carry out promotional activities, so that more readers can understand the activities of the library content and activities, but also can play the role of publicity activities. After the event, the results of the event can also be released through the public platform to attract more readers interest, so that they can be more frequently into the library activities to come.

\subsection{Recommend Books to Readers.}

The library can use the public platform to recommend books to readers, increase the reader's interest in library books, and attract more potential readers to read. 


\section{Why Should The Establishment of Wechat Public Number}

\subsection{The Needs of Teachers and Students in Colleges and Universities Are}

increasingly diversified. After entering the twenty-first century, college teachers and students on the library requirements are getting higher and higher, so the library will be able to convey more fresh content for readers to read. In addition, in recent years, according to the results of the study of scientists show that people's reading time is increasingly showing the trend of fragmentation, so, and people used to read the afternoon or a day to read, and now people need a short time Finished reading. With the Internet platform, you can push a lot of books and information at the same time, the reader can choose from their own content of interest to read, at the same time, WeChat public number push the length of the content is shorter, allowing readers in a short time can Complete the reading, in line with the current fragmented reading of the actual situation. In addition, the WeChat public number can also be simple to achieve personalized push, for each reader's different needs, to push them different information to meet today's development needs.

\subsection{The Requirements for Library Service Efficiency Are Also Increasing.}

Many colleges and universities in our country will focus on the development of the library on the scale of the expansion of the above, blindly expand the size of the library staff led to a serious shortage of staff, work efficiency is seriously reduced. Some libraries also take into account the efficiency of work, increase staff, increase the number of collections, increase the size of the library, but it ignores the needs of teachers and students, the library is a project for teachers and students, if the college managers blindly In order to increase the performance and expansion of the library, ignoring the teachers and students of the practical needs of the library, teachers and students will cause dissatisfaction. Therefore, the university managers in the construction of the library work, from the reality, earnestly listen to the views of teachers and students to increase the use of new science and technology in the library, while improving the efficiency of the work, so that teachers and students have a more friendly The service experience.

\subsection{The Quality of Library Services Is Also Getting Higher and Higher.}

In addition to increasing the efficiency of the library's services, it is also important to increase the quality of library services. In addition to pushing the news to the student, the student can also use the WeChat public platform for feedback. Library management staff to read these feedback in a timely manner, listen to the recommendations of teachers and students, there is no change to add Mian, which can significantly improve the quality of library services, establish a good image. Library managers can also understand the status of students through micro-letter, timely understanding of the students' inner thoughts and personal preferences, so that teachers and students can provide more quality services.

\section{The Significance of the Application of Micro - Letter Public Numbers in University Libraries}

\subsection{Open the Management of The Building Ideas.}

The establishment of WeChat public number, you can give managers and teachers and students a better platform for the exchange of the two sides can exchange their views on the library. Managers can learn from the WeChat public number of some good suggestions and ideas, active in their own ideas, you can better carry out the construction of the library work. At the same time, it also helps to change the manager's own ideas, so that they can timely access to external information, selfinnovation, and the trend of the times. At the same time, the library management staff can also be based on the public number of feedback to improve their services. In addition, the library management staff can also use the WeChat public platform to improve the visibility of the library.

\subsection{To Improve the Awareness of School Teachers and Students.}

Cognition reflects whether people have some knowledge of their own things. Library of the WeChat public platform, teachers and students can provide some useful information, but also to answer the various problems of students, teachers and students to enhance the understanding of the library to improve their awareness. For example, the library can be in the new knowledge and 
information, the first time with the micro-public platform to push, so that readers can in the shortest possible time to obtain cutting-edge knowledge.

\subsection{Break the Limitations of Space.}

The development of science and technology, will gradually reduce the space brought about by the problem. In ancient times, students often go all the way to the school to go to school by school, after the invention of the train, the students go to school has become more convenient. After creating the microblogging public platform, students can quickly and efficiently acquire knowledge on the mobile side by accessing the microblogging public platform. Students can stay at home to read their own books, see what they want to see the information. Breaking the limitations of space and time, so that students can do anytime, anywhere learning. Students in the WeChat through the acquisition of knowledge at the same time, you can also micro-information platform for timely feedback to the library management staff to say their needs, the library received the information, you can optimize their own services to improve their own The quality of service and external image. In addition, students can also through the establishment of micro-credit group to achieve the exchange between each other, to facilitate the exchange of the process, making the exchange between students become more convenient. Therefore, the WeChat platform indirectly facilitates the exchange of students. So that students can better understand the library, improve the awareness of students.

\subsection{Expand the Scope of Library Services.}

Most of the traditional university library service students are college students, rarely accept the outside world people come to the library to study, the service side is narrow. The university library with WeChat public number platform, the service object is also a number of social awareness, the university library can use the public number to provide reading services to the community, which is consistent with the national policy call, but also to achieve today's universal Reading the atmosphere. So, in this sense, the WeChat public platform to break the campus of the knowledge of the imprisonment, so that the library materials in the library can effectively help the community to learn. But also can improve the school's visibility and social influence, the school has a very important significance. In addition, the community can also participate in the activities of the readers' exchange meeting organized by the WeChat platform so that the community can also communicate with the students so that the community can learn the relevant knowledge content.

\subsection{Improve the Quality of Service.}

As the contents of the library collection for many years, will inevitably appear improper situation, coupled with the reader's love of books is not enough, it is easy to cause damage to books and other conditions, which will give readers a bad reading experience. And after the opening of the WeChat public number, the library manager can be paper-based books for electronic scanning, made of electronic files, and then placed on the micro-signal for the needs of readers to download, which can greatly improve the reader's reading Experience. In addition, the borrowing situation, the collection of books and other information can also be placed on the micro-public platform, teachers and students can according to their own needs at any time to view, rather than frequent to the library, teachers and students to borrow activities More convenient. The microblogged public number can also integrate the resources of the library.

In addition to collection of resources in the library, there are some other electronic resources, teachers and students to borrow to the library when the time to see these resources, the probability of small, to a certain extent, caused a waste of resources. WeChat public number can be all the resources of the library to integrate, so that teachers and students can get all the resources in their own resources, greatly enhance the quality of the service.

\section{Conclusion}

The current function of the WeChat is still constantly under development, with the development of the function will certainly be more powerful, it will be more convenient to use. The university library should conform to the trend of the development of the times, strengthen the construction of the public letter of the WeChat, so that the public information can help the library. At the same time, the new technology is also on the equipment and human resources on the library made a greater 
challenge, as managers, to actively overcome these challenges, so that the library can provide more quality services.

\section{References}

[1]. Li Jian. An Analysis of the Application of Micro-public Platform in Reading and Popularization - A Case Study of University Libraries in Guangdong Province [J]. Library Research, 2015, 45 (4): 92-96.

[2]. Yao Xue. WeChat public platform in the university library reader service application [J]. China Science and Technology Information, 2015 (7): 68-68.

[3]. Li Jiaqi, Zhang Dongmin. WeChat public number in the university library service application research [J]. Computer knowledge and technology, 2017, 13 (11).

[4]. Huang Jinghua. WeChat public number in the university library service model innovation research [J]. Library, 2017 (2): 108-111.

[5]. [J]. Journal of Hebei Union University (Social Science Edition), 2016, 16 (4): 63- [J]. Journal of Hebei Union University (Social Science Edition) 67. 